\title{
Secoiridoids and Iridoids from Morinda asteroscepa
}

\author{
Linda Zandi, Marco Makungu, Joan J. E. Munissi, Sandra Duffy, Rakesh Puttreddy, \\ Daniel von der Heiden, Kari Rissanen, Vicky M. Avery, Stephen S. Nyandoro,* and Máté Erdélyi*
}

Cite This: https://dx.doi.org/10.1021/acs.jnatprod.0c00447

ABSTRACT: The new 2,3-secoiridoids morisecoiridoic acids A (1) and B (2), the new iridoid 8-acetoxyepishanzilactone (3), and four additional known iridoids (4-7) were isolated from the leaf and stem bark methanol extracts of Morinda asteroscepa using chromatographic methods. The structure of shanzilactone (4) was revised. The purified metabolites were identified using NMR spectroscopic and mass spectrometric techniques, with the absolute configuration of 1 having been established by single-crystal X-ray diffraction analysis. The crude leaf extract $(10 \mu \mathrm{g} / \mathrm{mL})$ and compounds $1-3$ and $5(10 \mu \mathrm{M})$ showed mild antiplasmodial activities against the chloroquine-sensitive malaria parasite Plasmodium falciparum (3D7).

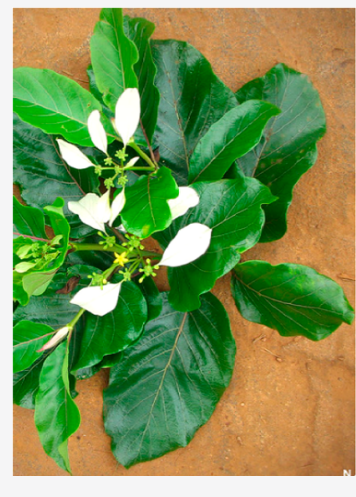<smiles>[R]C1(C)CC(O)C2C(C(=O)OC)CCOC(=O)C21[R]</smiles>

1,2

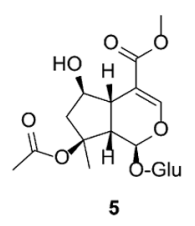

3,4

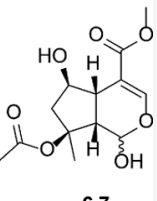

6,7
Morinda asteroscepa K. Schum is a small tree belonging to the family Rubiaceae and is endemic to Tanzania and Malawi. It has a limited distribution in Eastern Tanzania and in the Nchisi Forest in Malawi. ${ }^{1,2}$ The plant is classified as a vulnerable species in the International Union of Conservation of Nature (IUCN) Red List of Threatened Plant Species. ${ }^{1,2} M$. asteroscepa, locally known as "muromberombe" in Tanzania, is used in folk medicine as an antimalarial and anticonvulsant, especially for children. ${ }^{2}$ Previous reports of phytochemical investigations of Morinda species have revealed the genus to accumulate iridoids, glycosides, flavonoids, and anthraquinones, some of which are known for antidiabetic, ${ }^{3}$ antioxidant, $^{4,5}$ antimicrobial, ${ }^{6-8}$ antiviral, ${ }^{7}$ antitumor,,${ }^{6,9-11}$ antiinflammatory, ${ }^{6,12}$ immune-enhancing, ${ }^{6}$ antiosteoporotic, ${ }^{13}$ antimalarial, ${ }^{14}$ antihistamine, antihelmintic, and analgesic ${ }^{6}$ activities. Some other species of this genus, including M. citrifolia (Noni), are used in folk medicine for the treatment of abdominal colic, cancer, hypertension, malaria, and various types of fever. ${ }^{15-17} \mathrm{M}$. asteropscepa has not been phytochemically investigated before. Owing to the previously reported bioactive secondary metabolites of the genus and the medicinal uses of its species, it was included in our ongoing phytochemical investigation of rare and endemic Tanzanian medicinal plants. ${ }^{18-23}$ Herein, we report the isolation, identification, and determination of the antiplasmodial activities of the new 2,3-secoiridoids 1 and 2, the new iridoid 3, and four additional known iridoids, 4-7.

\section{RESULTS AND DISCUSSION}

Repeated gravitational column chromatographic separation of the $\mathrm{CH}_{3} \mathrm{OH}$ extract of the stem bark of $M$. asteroscepa over silica gel followed by purification using Sephadex LH-20 and
HPLC afforded the new secoiridoid 1 and the four known iridoids 4-7. The new natural product 1, along with two additional new compounds, $\mathbf{2}$ and 3 , were isolated from the $\mathrm{CH}_{3} \mathrm{OH}$ extract of the leaves. The compounds were identified using NMR spectroscopic and mass spectrometric techniques and were further verified by $\mathrm{CSEARCH},{ }^{24}$ and the structure of 1 was also confirmed by single-crystal X-ray crystallographic analysis.
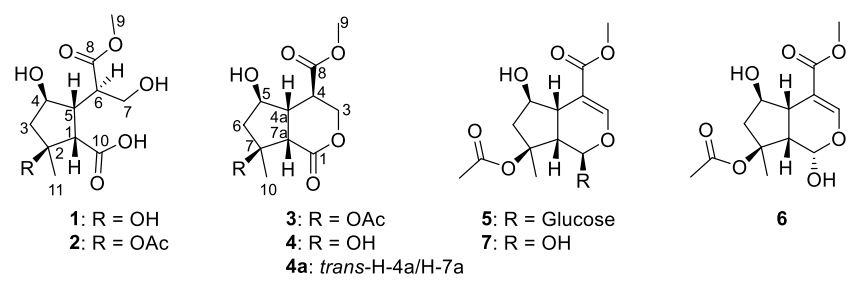

Compound $1\left\{[\alpha]^{20}{ }_{\mathrm{D}}-37.5\left(\right.\right.$ c 2.0, $\left.\left.\mathrm{CH}_{3} \mathrm{OH}\right)\right\}$, a major metabolite of the stem bark and the leaf extracts, was obtained as a white solid and was assigned the molecular formula $\mathrm{C}_{11} \mathrm{H}_{18} \mathrm{O}_{7}$ based on HRESIMS analysis $\left(m / z[\mathrm{M}+\mathrm{H}]^{+}\right.$ 263.1137, calcd 263.1131). The ${ }^{1} \mathrm{H}$ NMR data (Table 1) showed signals for two sets of diastereotopic protons at $\delta_{\mathrm{H}} 3.99$ $(\mathrm{H}-7 \mathrm{a}), 3.85(\mathrm{H}-7 \mathrm{~b})$ and $\delta_{\mathrm{H}} 2.42(\mathrm{H}-3 \mathrm{a}), 1.72(\mathrm{H}-3 \mathrm{~b})$, for four methine protons at $\delta_{\mathrm{H}} 4.40(\mathrm{H}-4), 2.87(\mathrm{H}-6), 2.78(\mathrm{H}-1)$, and

Received: April 23, 2020 
Table $1 .{ }^{1} \mathrm{H},{ }^{13} \mathrm{C}$, and HMBC NMR Spectroscopic Data for 1 $\left(800 \mathrm{MHz}\right.$, Methanol- $\left.d_{4}\right)$

\begin{tabular}{|c|c|c|c|}
\hline position & $\delta_{\mathrm{C}}$, type & $\delta_{\mathrm{H}}, \mathrm{m}(J$ in $\mathrm{Hz})$ & $\mathrm{HMBC}, \mathrm{H} \rightarrow \mathrm{C}$ \\
\hline 1 & $61.9, \mathrm{CH}$ & 2.78 , dd $(6.8,1.9)$ & $\begin{array}{l}\text { C-1, C-2, C-3, C-4, C-5, } \\
\text { C-10 }\end{array}$ \\
\hline 2 & $79.9, \mathrm{C}-\mathrm{O}$ & & \\
\hline \multirow[t]{2}{*}{3} & \multirow[t]{2}{*}{ 49.6, $\mathrm{CH}_{2}$} & 2.42 , dd $(14.6,9.6)$ & C-2, C-4, C-5, C-11 \\
\hline & & $\begin{array}{l}\text { 1.72, ddd }(14.6,2.5 \text {, } \\
1.9)\end{array}$ & C-1, C-2, C-4, C-5 \\
\hline 4 & 76.7, $\mathrm{HC}-\mathrm{OH}$ & $\begin{array}{l}\text { 4.40, ddd (9.6, 7.3, } \\
2.5)\end{array}$ & C-2, C-3, C-5, C-6 \\
\hline 5 & $50.2, \mathrm{CH}$ & $\begin{array}{l}\text { 2.70, ddd }(11.4,7.3 \text {, } \\
6.8)\end{array}$ & $\begin{array}{l}\text { C-1, C-3, C-4, C-6, C-7, } \\
\text { C- } 8\end{array}$ \\
\hline 6 & $51.0, \mathrm{CH}$ & $\begin{array}{l}\text { 2.87, ddd (11.4, 8.2, } \\
4.9)\end{array}$ & C-1, C-4, C-5, C-7, C-8 \\
\hline \multirow[t]{2}{*}{7} & \multirow[t]{2}{*}{$63.9, \mathrm{H}_{2} \mathrm{C}-\mathrm{OH}$} & 3.99 , dd $(11.2,4.9)$ & C-5, C-6, C-8 \\
\hline & & 3.85 , dd $(11.2,8.2)$ & C-5, C-6, C-8 \\
\hline 8 & $175.9, \mathrm{OC}=\mathrm{O}$ & & \\
\hline 9 & $51.9, \mathrm{OCH}_{3}$ & $3.69, \mathrm{~s}$ & $\mathrm{C}-8$ \\
\hline 10 & $175.8, \mathrm{COOH}$ & & \\
\hline 11 & 25.5, $\mathrm{CH}_{3}$ & $1.29, \mathrm{~s}$ & C-1, C-2, C-3 \\
\hline
\end{tabular}

$2.70(\mathrm{H}-5)$, methyl group protons at $\delta_{\mathrm{H}} 1.29(\mathrm{H}-11)$, and methoxy group protons at $\delta_{\mathrm{H}} 3.69(\mathrm{H}-9)$, as confirmed by multiplicity-edited HSQC data. The COSY and TOCSY coupling patterns of these signals suggested the presence of a cyclic structure; thus, $\mathrm{H}-3 \mathrm{a} / \mathrm{b}\left(\delta_{\mathrm{H}} 2.42\right.$ and 1.72$)$ couples to $\mathrm{H}-$ $4\left(\delta_{\mathrm{H}} 4.40\right)$ with ${ }^{3} J_{\mathrm{HH}} 2.5$ and $9.6 \mathrm{~Hz}, \mathrm{H}-4$ to $\mathrm{H}-5\left(\delta_{\mathrm{H}} 2.70\right)$ with ${ }^{3} J_{\mathrm{HH}} 7.3 \mathrm{~Hz}$, and $\mathrm{H}-5$ to $\mathrm{H}-1\left(\delta_{\mathrm{H}} 2.78\right)$ with ${ }^{3} J_{\mathrm{HH}} 1.9 \mathrm{~Hz}$. In addition $\mathrm{H}-1\left(\delta_{\mathrm{H}} 2.78\right)$ gave ${ }^{3} \mathrm{~J} \mathrm{HMBC}$ correlation to $\mathrm{C}-3$ $\left(\delta_{\mathrm{C}} 49.6\right)$, and $\mathrm{H}-3\left(\delta_{\mathrm{H}} 2.42\right)$ to C-1 $\left(\delta_{\mathrm{C}} 61.9\right)$. The ${ }^{13} \mathrm{C} \mathrm{NMR}$ spectrum indicated the presence of 11 magnetically nonequivalent carbons, of which two were carbonyls at $\delta_{\mathrm{C}} 175.8$ (C-10) and 175.9 (C-8) with their chemical shifts being compatible with carboxylic acid or ester functionalities. An oxygenated tertiary carbon at $\delta_{\mathrm{C}} 79.9(\mathrm{C}-2)$, two additional oxygenated carbons at $\delta_{\mathrm{C}} 76.7$ (C-4) and 63.9 (C-7), a methoxy carbon at $\delta_{\mathrm{C}} 50.2(\mathrm{C}-9)$, and five aliphatic carbons at $\delta_{\mathrm{C}} 25.5$ (C-1), 61.9 (C-1), 49.6 (C-3), 50.2 (C-5), and 51.0 (C-6) were also detected. The cyclic structure of 1 was confirmed by the HMBC cross-peaks of H-11 $\left(\delta_{\mathrm{H}} 1.29\right), \mathrm{H}-4$ $\left(\delta_{\mathrm{H}} 4.40\right), \mathrm{H}-3 \mathrm{a}, \mathrm{b}\left(\delta_{\mathrm{H}} 2.42,1.72\right)$, and $\mathrm{H}-1\left(\delta_{\mathrm{H}} 2.78\right)$ with the oxygenated tertiary carbon $\mathrm{C}-2(\delta \mathrm{c} 79.9)$, after the C-3-C-4C-5-C-1 connectivity was established based on COSY, TOCSY, and HMBC data. Hence, HMBC cross-peaks were observed between H-3a,b $\left(\delta_{\mathrm{H}} 2.42,1.72\right)$ and C-5 $\left(\delta_{\mathrm{C}} 50.2\right)$, while $\mathrm{H}-5,\left(\delta_{\mathrm{H}} 2.70\right)$ showed HMBC correlation to C-1 $\left(\delta_{\mathrm{C}}\right.$ 61.9). Proton $\mathrm{H}-1\left(\delta_{\mathrm{H}} 2.78\right)$ exhibited a ${ }^{4} J_{1,3 \mathrm{~b}}=1.9 \mathrm{~Hz} W$ coupling, observed by ${ }^{1} \mathrm{H}$ NMR, COSY, and TOCSY spectra, compatible with the proposed cyclic structure. The position of $\mathrm{CH}_{3} \mathrm{O}-9\left(\delta_{\mathrm{H}} 3.67\right)$ was revealed by its $\mathrm{HMBC}$ correlation to C-8 ( $\delta \mathrm{c} 175.9)$, confirming the presence of an ester moiety. The position of the ester carbonyl was established by its HMBC correlation to the diastereotopic protons $\mathrm{H}-7 \mathrm{a}, \mathrm{b}\left(\delta_{\mathrm{H}}\right.$ $3.99,3.85)$ and H-5 $\left(\delta_{\mathrm{H}} 2.70\right)$. Proton H-6 $\left(\delta_{\mathrm{H}} 2.87\right)$ showed scalar couplings to $\mathrm{H}-7 \mathrm{a}, \mathrm{b}\left(\delta_{\mathrm{H}} 3.99,3.85\right)$ and $\mathrm{H}-5\left(\delta_{\mathrm{H}} 2.70\right)$, indicating the fragment $\mathrm{C}-7-\mathrm{C}-6-\mathrm{C}-5$. The carbonyl carbon C-10 $\left(\delta_{\mathrm{C}} 175.8\right)$ was established to be within a three-bond distance to $\mathrm{H}-5\left(\delta_{\mathrm{H}} 2.70\right)$ by $\mathrm{HMBC}$ spectroscopy. NOE correlations between $\mathrm{H}_{3}-11\left(\delta_{\mathrm{H}} 1.29\right)$ and $\mathrm{H}-3 \mathrm{a}\left(\delta_{\mathrm{H}} 2.42\right)$ and between $\mathrm{H}-3 \mathrm{a}\left(\delta_{\mathrm{H}} 2.42\right)$ and $\mathrm{H}-4\left(\delta_{\mathrm{H}} 4.40\right)$ indicated these protons to be cofacial. Proton $\mathrm{H}-4\left(\delta_{\mathrm{H}} 4.40\right)$ showed NOE correlations with the side chain protons $\mathrm{H}-6\left(\delta_{\mathrm{H}} 2.87\right)$ and $\mathrm{H}-$ 7a $\left(\delta_{\mathrm{H}} 3.99\right)$. Proton $\mathrm{H}-11\left(\delta_{\mathrm{H}} 1.29\right)$ also showed a weak NOE correlation with H-1 $\left(\delta_{\mathrm{H}} 2.78\right)$, indicating their transrelationship (strong NOE would be expected for the cisisomer). Compound 1 crystallized from a 1:1 iso-hexaneEtOAc mixture at room temperature. The compound was analyzed by single-crystal X-ray diffraction, confirming its structure, including the absolute configurations of the five stereogenic carbons (Figure 1). Therefore, the new mor-

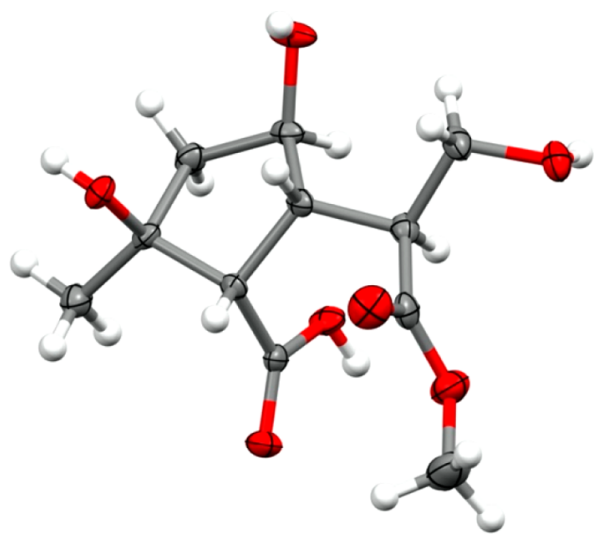

Figure 1. X-ray crystal ORTEP drawing of morisecoiridoic acid A (1, CCDC 1963302). The thermal displacement parameters are shown at the $60 \%$ probability level.

isecoiridoic acid A (1) was characterized as (1S,2S,4R,5R)-2,4dihydroxy-5-[(R)-3-hydroxy-1-methoxy-1-oxopropan-2-yl]-2methylcyclopentane-1-carboxylic acid.

Compound $2\left\{[\alpha]^{20}-25.0\left(c 2.0, \mathrm{CH}_{3} \mathrm{OH}\right)\right\}$, isolated from the $\mathrm{CH}_{3} \mathrm{OH}$ extract of the leaves, was obtained as white solid and was assigned the molecular formula $\mathrm{C}_{13} \mathrm{H}_{20} \mathrm{O}_{8}$ based on HRESIMS data analysis $\left(\mathrm{m} / z[\mathrm{M}+\mathrm{H}]^{+} 305.1204\right.$, calcd 305.1236). ${ }^{1} \mathrm{H}$ and ${ }^{13} \mathrm{C}$ NMR data (Table 2) together with $2 \mathrm{D}$ spectra showed similar spectroscopic features to those

Table 2. ${ }^{1} \mathrm{H},{ }^{13} \mathrm{C}$, and HMBC NMR Spectroscopic Data for 2 (600 MHz, Methanol- $d_{4}$ )

\begin{tabular}{|c|c|c|c|}
\hline position & $\delta_{\mathrm{C}}$, type & $\delta_{\mathrm{H}}, \mathrm{m}(J$ in $\mathrm{Hz})$ & HMBC, $\mathrm{H} \rightarrow \mathrm{C}$ \\
\hline 1 & $59.6, \mathrm{CH}$ & 3.24 , dd $(6.8,1.9)$ & $\begin{array}{l}\text { C-2, C-3, C-4, C-5, C-6, } \\
\text { C-10, C-11 }\end{array}$ \\
\hline 2 & $90.2, \mathrm{C}-\mathrm{O}$ & & \\
\hline \multirow[t]{2}{*}{3} & 47.2, $\mathrm{CH}_{2}$ & $\begin{array}{l}\text { 2.43, dd (14.6, } \\
9.2)\end{array}$ & C-1, C-2, C-4, C-5, C-11 \\
\hline & & $\begin{array}{l}2.35, \mathrm{ddd},(14.6, \\
2.8,1.9)\end{array}$ & \\
\hline 4 & 75.9, $\mathrm{HC}-\mathrm{OH}$ & $\begin{array}{l}\text { 4.40, ddd (9.2, } \\
\quad 7.3,2.8)\end{array}$ & C-1, C-2, C-3, C-5, C- 6 \\
\hline 5 & 49.9, $\mathrm{CH}$ & $\begin{array}{l}\text { 2.50, ddd (11.6, } \\
\quad 7.3,6.8)\end{array}$ & $\begin{array}{l}\text { C-1, C-3, C-4, C-6, C-7, } \\
\text { C-8 }\end{array}$ \\
\hline 6 & $50.9, \mathrm{CH}$ & $\begin{array}{l}\text { 2.83, ddd (11.6, } \\
8.0,4.9)\end{array}$ & C-1, C-4, C-5, C-7, C-8 \\
\hline \multirow[t]{2}{*}{7} & 63.9, $\mathrm{H}_{2} \mathrm{C}-\mathrm{OH}$ & $\begin{array}{l}\text { 3.96, dd (11.2, } \\
4.9)\end{array}$ & C-5, C-6, C-8 \\
\hline & & $\begin{array}{l}3.82, \text { dd }(11.2, \\
8.0)\end{array}$ & \\
\hline 8 & $175.9, \mathrm{OC}=\mathrm{O}$ & & \\
\hline 9 & $52.1, \mathrm{OCH}_{3}$ & $3.68, \mathrm{~s}$ & C-8 \\
\hline 10 & $174.6, \mathrm{COOH}$ & & \\
\hline 11 & $21.2, \mathrm{CH}_{3}$ & $1.54, \mathrm{~s}$ & C-1, C-2, C-3 \\
\hline 13 & $172.3, \mathrm{OC}=\mathrm{O}$ & & \\
\hline 14 & 22.5, $\mathrm{CH}_{3}$ & $2.03, \mathrm{~s}$ & $\mathrm{C}-13$ \\
\hline
\end{tabular}


observed for compound 1, except for additional signals due to its acetoxy functionality $\left(\delta_{\mathrm{H}} 2.02,3 \mathrm{H} ; \delta_{\mathrm{C}} 22.5\right.$ and 172.3) and associated minor chemical shift differences. The position of the acetoxy group was assigned to $\mathrm{C}-2$ due to its deshielded chemical shift $\left(\delta_{\mathrm{C}} 79.9\right.$ in $\mathbf{1}, \delta_{\mathrm{C}} 90.2$ in 2 ). Other noticeable chemical shift differences as compared to 1 were detected for $\mathrm{H}-3 \mathrm{~b}\left(\delta_{\mathrm{H}} 1.72\right.$ to $\left.\delta_{\mathrm{H}} 2.35\right)$ and $\mathrm{H}-1\left(\delta_{\mathrm{H}} 2.78\right.$ to $\left.\delta_{\mathrm{H}} 3.24\right)$ and for the corresponding carbons being shielded from $\delta_{\mathrm{C}} 49.6$ to $\delta_{\mathrm{C}} 47.2(\mathrm{C}-3)$ and $\delta_{\mathrm{C}} 61.9$ to $\delta_{\mathrm{C}} 59.6(\mathrm{C}-1)$. As for compound 1, H-1 $\left(\delta_{\mathrm{H}} 3.24\right)$ of 2 also exhibited a ${ }^{4} J_{1,3 \mathrm{~b}}=1.9 \mathrm{~Hz} W$ coupling. The similar NOESY correlations of compound $\mathbf{2}$ (Figure S14, Supporting Information) to those observed for 1, along with both being levorotatory, indicated $\mathbf{1}$ and $\mathbf{2}$ to have the same absolute configurations. Based on the spectroscopic evidence, the new morisecoiridoic acid B (2) was characterized as $(1 S, 2 S, 4 R, 5 R)$-2-acetoxy-4-hydroxy-5-[( $R)$-3-hydroxy-1-methoxy-1-oxopropan-2-yl]-2-methylcyclopentane-1-carboxylic acid.

Compound $3\left\{[\alpha]_{D}^{20}+35.0\left(c 2.0, \mathrm{CH}_{3} \mathrm{OH}\right)\right\}$, isolated from the leaf $\mathrm{CH}_{3} \mathrm{OH}$ extract of $M$. asteroscepa, was obtained as a white solid and was assigned the molecular formula $\mathrm{C}_{13} \mathrm{H}_{18} \mathrm{O}_{7}$ based on HRESIMS data analysis $\left(m / z[\mathrm{M}+\mathrm{H}]^{+} 287.1115\right.$, calcd 287.1131). The ${ }^{1} \mathrm{H},{ }^{13} \mathrm{C}$ (Table 3), COSY, TOCSY,

Table 3. ${ }^{1} \mathrm{H},{ }^{13} \mathrm{C}$, and HMBC NMR Spectroscopic Data for 3 (800 MHz, Methanol- $d_{4}$ )

\begin{tabular}{|c|c|c|c|}
\hline position & $\delta_{\mathrm{C}}$, type & $\delta_{\mathrm{H}}, \mathrm{m}(J$ in $\mathrm{Hz})$ & $\mathrm{HMBC}, \mathrm{H} \rightarrow \mathrm{C}$ \\
\hline 1 & $171.8, \mathrm{OC}=\mathrm{O}$ & & \\
\hline \multirow[t]{2}{*}{3} & $68.5, \mathrm{H}_{2} \mathrm{C}-\mathrm{O}$ & 4.53 , dd $(12.2,4.0)$ & C-1, C-4, C-4a, C-8 \\
\hline & & $\begin{array}{l}\text { 4.51, ddd, (12.2, } \\
\quad 5.3,1.2)\end{array}$ & \\
\hline 4 & 42.5, CH & $\begin{array}{l}\text { 2.90, ddd }(5.3,5.3 \text {, } \\
4.0)\end{array}$ & $\begin{array}{l}\text { C-3, C-4a, C-5, C-7a, C- } \\
8\end{array}$ \\
\hline $4 a$ & 45.6, $\mathrm{CH}$ & $\begin{array}{l}\text { 2.80, dddd (12.0, } \\
7.9,5.3,1.2)\end{array}$ & $\begin{array}{l}\text { C-3, C-4, C-5, C-6, C- } \\
\text { 7a, C-8 }\end{array}$ \\
\hline 5 & $74.2, \mathrm{HC}-\mathrm{OH}$ & $\begin{array}{l}\text { 4.08, ddd }(9.4,7.9 \text {, } \\
6.4)\end{array}$ & $\begin{array}{l}\text { C-4, C-4a, C-6, C-7, C- } \\
7 \mathrm{a}\end{array}$ \\
\hline \multirow[t]{2}{*}{6} & 46.4, $\mathrm{CH}_{2}$ & $2.59, \mathrm{dd}(12.8,6.4)$ & $\begin{array}{l}\text { C-4a, C-5, C-7, C-7a, C- } \\
10\end{array}$ \\
\hline & & $2.25, \mathrm{dd}(12.8,9.4)$ & \\
\hline 7 & 86.9, $\mathrm{C}-\mathrm{O}$ & & \\
\hline $7 a$ & $51.4, \mathrm{CH}$ & $3.73, \mathrm{~d}(12.0)$ & $\begin{array}{l}\text { C-1, C-4, C-4a, C-5, C- } \\
6, C-7, C-10\end{array}$ \\
\hline 10 & 23.1, $\mathrm{CH}_{3}$ & $1.50, \mathrm{~s}$ & C-7, C-8, C-9 \\
\hline 8 & $173.5, \mathrm{OC}=\mathrm{O}$ & & \\
\hline 9 & $53.0, \mathrm{OCH}_{3}$ & $3.77, \mathrm{~s}$ & C-8 \\
\hline 11 & $172.0, \mathrm{OC}=\mathrm{O}$ & & \\
\hline 12 & 22.1, $\mathrm{CH}_{3}$ & $2.04, \mathrm{~s}$ & C-1a \\
\hline
\end{tabular}

NOESY, HSQC, and HMBC NMR spectra of 3 indicated high structural similarity of its substituted cyclopentane moiety to those of $\mathbf{1}$ and 2 . However, significant spectroscopic differences associated with its C-3 $\left(\delta_{\mathrm{C}} 68.5\right), \mathrm{H}-3 \mathrm{a}\left(\delta_{\mathrm{H}} 4.53\right)$, and $\mathrm{H}-$ $3 \mathrm{~b}$ (4.51) were observed. Unlike compounds 1 and 2 , whose diastereotopic protons, H-7a,b did not show HMBC crosspeaks with the carboxylic carbon $\mathrm{C}-10$, the corresponding diastereotopic C-3 protons of $3\left(\delta_{\mathrm{H}} 4.53\right.$ and 4.51$)$ gave ${ }^{3} \mathrm{~J}$ HMBC correlations with the carbonyl C-1 $\left(\delta_{\mathrm{C}} 171.8\right)$, in addition to a second carbonyl at $\delta_{\mathrm{C}} 173.5$ (C-8). This suggested the presence of a second cyclic moiety, identified as a $\delta$-lactone ring. Compound $\mathbf{2}$ may be converted to 3 by the intramolecular esterification of HO-7 and the C-10 hydroxycarbonyl group, resulting in a $\delta$-lactone. The lactonization to form the iridolactone moiety led to changes in chemical shifts and multiplicities (Table 3). Hence, concomitant with the disappearance of the ${ }^{4} J_{6 \mathrm{~b}, 7 \mathrm{a}}$ coupling, present in $\mathbf{1}$ and $2\left({ }^{4} J_{1,3 \mathrm{~b}}\right)$, the ${ }^{4} J_{3 \mathrm{~b}, 4 \mathrm{a}}=1.2 \mathrm{~Hz} W$-coupling was evident in 3 . Its $J_{4 \mathrm{a}, 7 \mathrm{a}}$ value increased to the upper limits of the cis-form, $12.0 \mathrm{~Hz}$, due to an eclipsed relationship $\left(\theta=0^{\circ}\right)$, unlike in compounds 1 and 2 , in which these protons exhibited an intermediate cis-coupling (gauche relationship, $J_{1,5}=6.8 \mathrm{~Hz}$ ). Such a large coupling $(12.0$ $\mathrm{Hz}$ ) can also be observed for trans-disposed ring protons having an anti-relationship. However, the cis-orientation of $\mathrm{H}$ $4 \mathrm{a}\left(\delta_{\mathrm{H}} 2.80\right)$ and $\mathrm{H}-7 \mathrm{a}\left(\delta_{\mathrm{H}} 3.73\right)$ was supported by their strong NOE correlation that confirmed the relative configurations of the corresponding stereogenic carbons. The NOE correlation of $\mathrm{H}-4 \mathrm{a}\left(\delta_{\mathrm{H}} 2.80\right)$ with $\mathrm{H}-6 \mathrm{~b}\left(\delta_{\mathrm{H}} 2.25\right)$ and $\mathrm{H}-3 \mathrm{~b}\left(\delta_{\mathrm{H}} 4.51\right)$ indicated these protons to be on the same convex side of the molecule. A second set of strong NOE correlations between $\mathrm{H}$ $10\left(\delta_{\mathrm{H}} 1.50\right)$ and H-6a $\left(\delta_{\mathrm{H}} 2.59\right), \mathrm{H}-5\left(\delta_{\mathrm{H}} 4.08\right), \mathrm{H}-4\left(\delta_{\mathrm{H}}\right.$ $2.90)$, and $\mathrm{H}-3 \mathrm{a}\left(\delta_{\mathrm{H}} 4.53\right)$ revealed another set of protons in cis-relationship, covering the concave side of the molecule. The $\mathrm{CH}_{3}-10$ hydrogens $\left(\delta_{\mathrm{H}} 1.50\right)$ showed a weak NOE correlation to $\mathrm{H}-7 \mathrm{a}\left(\delta_{\mathrm{H}} 3.73\right)$, but did not show NOE correlation to $\mathrm{H}-4 \mathrm{a}$ $\left(\delta_{\mathrm{H}} 2.80\right)$, confirming the anti-orientation of $\mathrm{Me}-10$ and $\mathrm{H}-7 \mathrm{a}$. On the basis of the above spectroscopic data, the new iridoid $8 \beta$-acetoxy-epishanzilactone (3) was characterized as methyl (4 $\alpha, 4 \mathrm{a} \beta, 5 \alpha, 7 \alpha, 7 \mathrm{a} \beta)$-7-acetoxy-5-hydroxy-7-methyl-1-oxooctahydrocyclopenta $[c]$ pyran-4-carboxylate.

Compound 4, obtained as a white solid from the $\mathrm{CH}_{3} \mathrm{OH}$ extract of the leaves. Its ESIMS spectrum was compatible with the molecular formula $\mathrm{C}_{11} \mathrm{H}_{16} \mathrm{O}_{6}\left(\mathrm{~m} / z 245.2[\mathrm{M}+\mathrm{H}]^{+}\right)$. The NMR data (Table 4 ) revealed high structural similarities to 3 ,

Table 4. ${ }^{1} \mathrm{H},{ }^{13} \mathrm{C}$, and HMBC NMR Spectroscopic Data for 4 (800 MHz, Methanol- $d_{4}$ )

\begin{tabular}{|c|c|c|c|}
\hline position & $\delta_{\mathrm{C}}$, type & $\delta_{\mathrm{H}}, \mathrm{m}(J$ in $\mathrm{Hz})$ & $\mathrm{HMBC}, \mathrm{H} \rightarrow \mathrm{C}$ \\
\hline 1 & $172.5, \mathrm{OC}=\mathrm{O}$ & & \\
\hline \multirow[t]{2}{*}{3} & $66.9, \mathrm{H}_{2} \mathrm{C}-\mathrm{O}$ & 4.42 , dd $(12.1,4.0)$ & C-1, C-4, C-4a, C-8 \\
\hline & & $\begin{array}{l}\text { 4.40, ddd (12.1, } 5.8 \text {, } \\
\quad 1.2)\end{array}$ & \\
\hline 4 & $40.6, \mathrm{CH}$ & $\begin{array}{l}3.19 \text {, ddd }(10.0,5.8 \text {, } \\
4.0)\end{array}$ & $\begin{array}{l}\text { C- } 3 \text {, C- } 4 a, C-5, C-7 a, \\
\text { C- } 8\end{array}$ \\
\hline $4 a$ & 46.1, CH & $\begin{array}{l}\text { 2.86, dddd (10.0, } \\
\quad 8.0,6.0,1.2)\end{array}$ & $\begin{array}{l}\text { C-3, C-4, C-5, C-6, C- } \\
\text { 7a, C-8 }\end{array}$ \\
\hline 5 & 71.2, $\mathrm{HC}-\mathrm{OH}$ & $\begin{array}{l}\text { 4.11, ddd (10.0, 8.0, } \\
6.0)\end{array}$ & $\begin{array}{l}\text { C-4, C-4a, C-6, C-7, } \\
\text { C-7a }\end{array}$ \\
\hline \multirow[t]{2}{*}{6} & $50.6, \mathrm{CH}_{2}$ & 2.06 , dd $(12.1,6.0)$ & $\begin{array}{l}\text { C-4a, C-5, C-7, C-7a, } \\
\text { C-10 }\end{array}$ \\
\hline & & $1.94, \mathrm{dd}(12.1,10.0)$ & \\
\hline 7 & $78.6, \mathrm{C}-\mathrm{OH}$ & & \\
\hline $7 \mathrm{a}$ & $55.1, \mathrm{CH}$ & $3.34, \mathrm{~d}(12.2)$ & $\begin{array}{l}\text { C-1, C- } 4, \text { C- } 4 a, C-5, C- \\
\text { 6, C-7, C- } 10\end{array}$ \\
\hline 10 & $25.9, \mathrm{CH}_{3}$ & $1.29, \mathrm{~s}$ & $\mathrm{C}-6, \mathrm{C}-7, \mathrm{C}-7 \mathrm{a}$ \\
\hline 8 & $172.6, \mathrm{OC}=\mathrm{O}$ & & \\
\hline 9 & $52.0, \mathrm{OCH}_{3}$ & $3.77, \mathrm{~s}$ & C-8 \\
\hline
\end{tabular}

indicating a substituted cyclopenta $[c]$ pentanolactone iridoid core, arising from cyclization of hydroxy groups on $\mathrm{C}-1$ and $\mathrm{C}$ 3. ${ }^{25-29}$ Unlike compound 3, this iridoid had a hydroxy instead of an acetoxy functionality at C-7, with minor chemical shift displacements being indicative of the position of substitution (Table 4). The C-3 methylene protons $\left(\delta_{\mathrm{H}} 4.40\right.$ and 4.42$)$ exhibited ${ }^{3} J$ HMBC correlation with the carboxylic carbon $\mathrm{C}-1$ $\left(\delta_{\mathrm{C}}\right.$ 172.5), proving the esterification into an iridolactone moiety, which was further corroborated by the $W$-coupling ${ }^{4} J_{3 \mathrm{~b}, 4 \mathrm{a}}=1.2 \mathrm{~Hz}$. In addition, $\mathrm{H}-4 \mathrm{a}\left(\delta_{\mathrm{H}} 2.86\right)$ showed a large ${ }^{3} J_{4 a, 7 a}$ value of $12.2 \mathrm{~Hz}$, supporting the eclipsed cis-orientation 
of the involved protons, and a strong NOE correlation to $\mathrm{H}-7 \mathrm{a}$ $\left(\delta_{\mathrm{H}} 3.34\right)$, further corroborating the cis-orientation of these protons. Furthermore, this was also supported by the NOE correlation observed of the cis-oriented $\mathrm{H}-4 \mathrm{a}\left(\delta_{\mathrm{H}} 2.86\right)$ with $\mathrm{H}$ $6 \mathrm{~b}\left(\delta_{\mathrm{H}} 1.94\right)$ and $\mathrm{H}-3 \mathrm{~b}\left(\delta_{\mathrm{H}} 4.40\right)$ on the convex side. For the concave side, the strong NOEs of $\mathrm{H}_{3}-10\left(\delta_{\mathrm{H}} 1.29\right)$ to $\mathrm{H}-6 \mathrm{a}\left(\delta_{\mathrm{H}}\right.$ $2.06), \mathrm{H}-5\left(\delta_{\mathrm{H}} 4.11\right)$, and $\mathrm{H}-3 \mathrm{a}\left(\delta_{\mathrm{H}} 4.42\right)$ revealed these protons to be cis-oriented as well. Similar to $3, \mathrm{H}_{3}-10\left(\delta_{\mathrm{H}} 1.29\right)$ of 4 showed weak NOE correlation to $\mathrm{H}-7 \mathrm{a}\left(\delta_{\mathrm{H}} 3.34\right)$, but did not show NOE to $\mathrm{H}-4 \mathrm{a}\left(\delta_{\mathrm{H}} 2.86\right)$. Based on the spectroscopic evidence above, this natural product, shanzilactone (4), was characterized as methyl $(4 \alpha, 4 \mathrm{a} \alpha, 5 \alpha, 7 \alpha, 7 \alpha)$-5,7-dihydroxy-7methyl-1-oxooctahydrocyclopenta $[c]$ pyran-4-carboxylate. Shanzilactone was originally reported from Mussaenda incana ${ }^{25}$ with $4 \mathbf{a}$ as its structure. Its $\mathrm{H}-4 \mathrm{a}$ and $\mathrm{H}-7 \mathrm{a}$ were suggested to be in a trans-disposed orientation, based on the $J_{5,9}=12.0 \mathrm{~Hz}$, however without NOE data analysis. As indicated by the above analysis, particularly by the strong NOE observed between $\mathrm{H}$ $4 \mathrm{a}\left(\delta_{\mathrm{H}} 2.86\right)$ and H-7a $\left(\delta_{\mathrm{H}} 3.34\right)$, the NOEs of H-6b $\left(\delta_{\mathrm{H}} 1.94\right)$ with $\mathrm{H}-4 \mathrm{a}\left(\delta_{\mathrm{H}} 2.86\right)$ and $\mathrm{H}-7 \mathrm{a}\left(\delta_{\mathrm{H}} 3.34\right)$, and the absence of an NOE from H-6a $\left(\delta_{\mathrm{H}} 2.06\right)$ to $\mathrm{H}-4 \mathrm{a}$ or $\mathrm{H}-7 \mathrm{a}$, the earlier reported structure is incorrect. Neither is the similar chemical shift of H-4a $\left(\delta_{\mathrm{H}} 2.86\right)$ and $\mathrm{H}-7 \mathrm{a}\left(\delta_{\mathrm{H}} 3.34\right)$ compatible with a trans-orientation of these protons. The $J_{4 a, 7 a}$ value of $12.0 \mathrm{~Hz}$ is compatible with the proposed eclipsed cis-orientation of these protons. The structure of $4 \mathrm{a}$ is therefore revised to 4 .

The secondary metabolites barlerin $(5),{ }^{26,27} 8$-acetylshanzhigenin methyl ester (6), ${ }^{29,30}$ and 8-acetyl-1-epishanzhigenin methyl ester $(7)^{29,30}$ were identified by comparison of their spectroscopic features (Tables S1 and S2, Supporting Information) to those previously published. 8-Acetylshanzhigenin methyl ester (6) and 8-acetyl-1-epishanzhigenin methyl ester (7) were obtained as an isomeric mixture. Compounds 6 and 7 have previously been reported from the family Lamiaceae only, ${ }^{29,30}$ and thus this is the first report of their occurrence in the Rubiaceae.

M. asteroscepa and other Morinda species are used in indigenous medicine for the treatment of malaria, and accordingly some secondary metabolites of the genus were reported to show antiplasmodial activities. ${ }^{14}$ The $\mathrm{CH}_{3} \mathrm{OH}$ extract of the leaves $(10 \mu \mathrm{g} / \mathrm{mL})$ and the isolated compounds 1-3 and $5(10 \mu \mathrm{M})$ showed insignificant activity against the chloroquine-resistant parasite Plasmodium falciparum (3D7) (Table S3, Supporting Information).

In conclusion, two new 2,3-secoiridoids (1 and 2) and a new iridoid (3) along with four known iridoids (4-7) were isolated from $M$. asteroscepa. The structure of shanzilactone (4) was revised. Some of the isolated compounds showed weak antiplasmodial activities.

\section{EXPERIMENTAL SECTION}

General Experimental Procedures. Optical rotations were determined using an Autopol II Rudolph Research Analytical WLG polarimeter at $589 \mathrm{~nm}$, at $24.1{ }^{\circ} \mathrm{C}$. NMR spectra were acquired on a Bruker Avance III HD $800 \mathrm{MHz}$, a Varian $600 \mathrm{MHz}$ Inova, or a Varian $500 \mathrm{MHz}$ VNMR-S spectrometer and were processed using MestReNova-10.0. The structural assignment was based on ${ }^{1} \mathrm{H}$ and ${ }^{13} \mathrm{C}$ NMR, COSY, NOESY, HSQC, and HMBC spectra. The solvent residual peak was used for chemical shift referencing (methanol- $d_{4}, \delta_{\mathrm{H}}$ 3.31 and $\delta_{\mathrm{C}} 49.00 ; \mathrm{CDCl}_{3}, \delta_{\mathrm{H}} 7.26$ and $\delta_{\mathrm{C}}$ 77.16). LC-ESIMS chromatograms were acquired on a PerkinElmer PE SCIEX API 150 EX instrument equipped with a Turbolon spray ion source and a Gemini $5 \mathrm{~mm} \mathrm{RPC} \mathrm{RP}_{18} 110 \AA$ column, applying an $\mathrm{H}_{2} \mathrm{O}-\mathrm{MeCN}$, 80:20-20:80 (0.2\% formic acid), gradient solvent system with a separation time of $8 \mathrm{~min}$. HRMS (ESI) was obtained with a QTOFLC/MS spectrometer (Stenhagen Analys Lab AB, Gothenburg, Sweden) using a $2.1 \times 30 \mathrm{~mm}, 1.7 \mu \mathrm{m}, \mathrm{RPC}_{18}$ column and $\mathrm{a}_{2} \mathrm{O}-$ $\mathrm{MeCN}$ gradient system (5:95-95:5 gradient and 0.2\% $\mathrm{HCOOH}$ ). Column chromatography (CC) was carried out using silica gel 60 (230-400 mesh). Analytical thin-layer chromatography (TLC) was performed on silica gel 60 F254 (Merck) precoated aluminum plates, which after development with an appropriate solvent system were visualized under UV light (254 and $366 \mathrm{~nm}$ ) and then sprayed with 4anisaldehyde reagent (prepared by mixing $3.5 \mathrm{~mL}$ of 4 -anisaldehyde with $2.5 \mathrm{~mL}$ of concentrated $\mathrm{H}_{2} \mathrm{SO}_{4}, 4 \mathrm{~mL}$ of glacial $\mathrm{HOAc}$, and 90 $\mathrm{mL}$ of $\mathrm{CH}_{3} \mathrm{OH}$ ) followed by heating for identification of UV-negative compounds and detection of the color change of the UV-positive spots. Gel filtration was carried out over Sephadex LH-20 (Pharmacia) suspended in $\mathrm{CH}_{2} \mathrm{Cl}_{2}-\mathrm{CH}_{3} \mathrm{OH}$ (1:1). Preparative HPLC was performed on a Waters 600E system using the Chromulan (Pikron Ltd.) software and an $\mathrm{RPC}_{8}$ Kromasil column $(250 \mathrm{~mm} \times 25$ $\mathrm{mm}$ ) with the solvent system $\mathrm{H}_{2} \mathrm{O}-\mathrm{CH}_{3} \mathrm{OH}$ (gradient, 90:10 to $0: 100$, for $20-40 \mathrm{~min}$, flow rate of $8-15 \mathrm{~mL} / \mathrm{min}$ ).

Plant Material. The stem bark and leaves of $M$. asteroscepa were collected in November 2014 from the Dindira Sakare forest along the path to Manka (altitude 1245 m; GPS 37 M 0436537/9448240) West Usambara, Korogwe District in Tanga Region, Tanzania. The plant was identified by Frank M. Mbago in the field and subsequently authenticated at the Herbarium, Botany Department of the University of Dar es Salaam, where the voucher specimen (FMM 3668) is deposited.

Extraction and Isolation. The air-dried and pulverized leaves and stem bark were extracted with $\mathrm{CH}_{3} \mathrm{OH}$ twice for $48 \mathrm{~h}$ at room temperature. The extracts were concentrated using a rotatory evaporator at $40{ }^{\circ} \mathrm{C}$, providing $57.9 \mathrm{~g}$ of crude stem bark extracts and $38.0 \mathrm{~g}$ of leaf extracts. Silica gel CC of the stem crude extract with an increasing amount of EtOAc in isohexane gave 65 fractions, $\sim 200$ $\mathrm{mL}$ each. The fractions were combined and concentrated based on TLC analysis. Morisecoiridoic acid A (1, $204.0 \mathrm{mg}$ ) was obtained from the silica gel column of the crude extract and crystallized overnight from the solvent at room temperature. Fractions 25-38 also afforded compound 1, which eluted with a gradient of isohexaneEtOAc (90:10 to 10:90), followed by $5 \% \mathrm{CH}_{3} \mathrm{OH}$ in EtOAc. Fractions $40-51$ contained barlerin $(5,20.3 \mathrm{mg})$, which eluted at $10 \%$ $\mathrm{CH}_{3} \mathrm{OH}$ in EtOAc. The fractions containing compounds 4, 6, and 7 were subjected to further purification. The combination of the impure fractions 22-24 was purified on Sephadex LH-20 with $\mathrm{CH}_{2} \mathrm{Cl}_{2}-$ $\mathrm{CH}_{3} \mathrm{OH}$ (1:1), giving 12 subfractions of $30 \mathrm{~mL}$ each, followed by additional purification of the subfractions $6-9$ over silica gel eluting with EtOAc-isohexane (9:1), which provided shanzhilactone (4, 12.6 $\mathrm{mg}$ ). The combined impure fractions $10-12$ were passed through Sephadex LH-20 using $\mathrm{CH}_{2} \mathrm{Cl}_{2}-\mathrm{CH}_{3} \mathrm{OH}$ (1:1), yielding 21 subfractions of approximately $30 \mathrm{~mL}$ each, of which 3-8 were combined and further purified on an additional Sephadex LH-20 column using $\mathrm{CH}_{2} \mathrm{Cl}_{2}-\mathrm{CH}_{3} \mathrm{OH}$ (1:1), yielding fractions from which fractions 5-8 were combined and run on HPLC using $\mathrm{H}_{2} \mathrm{O}-\mathrm{CH}_{3} \mathrm{OH}$ (gradient 90:10 to 0:100), providing the isomeric mixture of 6 and 7 (6.4 mg).

The crude $\mathrm{CH}_{3} \mathrm{OH}$ extract of the leaves $(38 \mathrm{~g}$ ) was fractionated and purified using a similar procedure to that described above, leading to the isolation of morisecoiridoic acid A (1, 80.4 mg), morisecoiridoic acid B $(2,13.3 \mathrm{mg})$, and 8-acetoxy-epi-shanzhilactone (3, $15.6 \mathrm{mg})$.

Morisecoiridoic acid $A$ (1): white solid; $[\alpha]^{20}{ }_{\mathrm{D}}-37.5$ (c 2.0, $\left.\mathrm{CH}_{3} \mathrm{OH}\right) ;{ }^{1} \mathrm{H}$ and ${ }^{13} \mathrm{C}$ NMR data, see Table 1 ; HRESIMS $[\mathrm{M}+\mathrm{H}]^{+}$ $m / z 263.1137$ (calcd for $\mathrm{C}_{11} \mathrm{H}_{18} \mathrm{O}_{7}, 263.1131$ ).

Morisecoiridoic acid B (2): white solid; $[\alpha]_{\mathrm{D}}^{20}-25.0$ (c 2.0, $\left.\mathrm{CH}_{3} \mathrm{OH}\right) ;{ }^{1} \mathrm{H}$ and ${ }^{13} \mathrm{C}$ NMR data, see Table 2; HRESIMS $[\mathrm{M}+\mathrm{H}]^{+}$ $(m / z) 305.1236$ (calcd for $\mathrm{C}_{13} \mathrm{H}_{20} \mathrm{O}_{8}, 305.1204$ ).

8-Acetoxy-epi-shanzhilactone (3): white solid; $[\alpha]^{20}{ }_{\mathrm{D}}+35.0(c$ 2.0, $\left.\mathrm{CH}_{3} \mathrm{OH}\right) ;{ }^{1} \mathrm{H}$ and ${ }^{13} \mathrm{C}$ NMR data, see Table 3; HRESIMS $[\mathrm{M}+$ $\mathrm{H}]^{+}(m / z) 287.1115$ (calcd for $\mathrm{C}_{13} \mathrm{H}_{18} \mathrm{O}_{7}, 287.1131$ ). 
Shanzhilactone (4): white, amorphous solid; ${ }^{1} \mathrm{H}$ and ${ }^{13} \mathrm{C}$ NMR data, see Table 4; MS (ESI) $[\mathrm{M}+\mathrm{H}]^{+}(\mathrm{m} / z) 245.2$ (calcd for $\mathrm{C}_{11} \mathrm{H}_{17} \mathrm{O}_{6}, 245.1$ ).

Barlerin (5): white, amorphous solid; $[\alpha]_{\mathrm{D}}^{20}-81.5$ (c 2.0, $\left.\mathrm{CH}_{3} \mathrm{OH}\right) ;{ }^{1} \mathrm{H}$ and ${ }^{13} \mathrm{C}$ NMR data, see Table S1; MS (ESI) $[\mathrm{M}+$ $\mathrm{H}]^{+}(m / z) 449.4$ (calcd for $\mathrm{C}_{19} \mathrm{H}_{28} \mathrm{O}_{12}, 449.4$ ).

8-Acetylshanzhigenin methyl ester (6): white, amorphous solid; ${ }^{1} \mathrm{H}$ and ${ }^{13} \mathrm{C}$ NMR data, see Table S2; MS (ESI) $(m / z)[\mathrm{M}+\mathrm{H}]^{+}$ 287.2 (calcd for $\mathrm{C}_{13} \mathrm{H}_{18} \mathrm{O}_{7}, 287.1$ ).

Antiplasmodial Asexual Assay. The antiplasmodial activity was determined using an imaging-based assay method as previously described. ${ }^{31}$ Human red blood cells for the culture of Plasmodium falciparum were provided by the Australian Red Cross Blood Bank following their routine MTA for nonclinical blood product supply. The antiplasmodial assay work undertaken is covered by the approval from the Griffith University Biosafety and Human Ethics Committee, GU ref no. ESK/03/12/HREC; 03/08/11019.

\section{ASSOCIATED CONTENT}

\section{(s) Supporting Information}

The Supporting Information is available free of charge at https://pubs.acs.org/doi/10.1021/acs.jnatprod.0c00447.

1D and 2D NMR spectra and HRESIMS for compounds 1-4; NMR data for compound 5-7 (PDF)

X-ray crystal data (CIF)

\section{AUTHOR INFORMATION}

\section{Corresponding Authors}

Máté Erdélyi - Department of Chemistry and Molecular Biology, University of Gothenburg, Gothenburg SE-412 96, Sweden; Department of Chemistry-BMC, Uppsala University, SE-751 23 Uppsala, Sweden; @orcid.org/0000-0003-03595970; Phone: +46-72-9999166; Email: mate.erdelyi@ kemi.uu.se

Stephen S. Nyandoro - Department of Chemistry and Molecular Biology, University of Gothenburg, Gothenburg SE412 96, Sweden; Chemistry Department, College of Natural and Applied Sciences, University of Dar es Salaam, Dar es Salaam, Tanzania; Phone: +255-754-206560;

Email: nyandoro@udsm.ac.tz

\section{Authors}

Linda Zandi - Department of Chemistry and Molecular Biology, University of Gothenburg, Gothenburg SE-412 96, Sweden

Marco Makungu - Department of Chemistry and Molecular Biology, University of Gothenburg, Gothenburg SE-412 96, Sweden; Chemistry Department, College of Natural and Applied Sciences, University of Dar es Salaam, Dar es Salaam, Tanzania

Joan J. E. Munissi - Chemistry Department, College of Natural and Applied Sciences, University of Dar es Salaam, Dar es Salaam, Tanzania

Sandra Duffy - Discovery Biology, Griffith Institute for Drug Discovery, Griffith University, Nathan Q1d 4111, Australia

Rakesh Puttreddy - Department of Chemistry, University of Jyvaskyla, FI-40014 Jyvaskyla, Finland; ๑ orcid.org/00000002-2221-526X

Daniel von der Heiden - Department of Chemistry-BMC, Uppsala University, SE-751 23 Uppsala, Sweden

Kari Rissanen - Department of Chemistry, University of Jyvaskyla, FI-40014 Jyvaskyla, Finland; 10 orcid.org/00000002-7282-8419

Vicky M. Avery - Discovery Biology, Griffith Institute for Drug Discovery, Griffith University, Nathan Q1d 4111, Australia

Complete contact information is available at: https://pubs.acs.org/10.1021/acs.jnatprod.0c00447

\section{Notes}

The authors declare no competing financial interest.

Original FIDs are available, open access, at Zenodo with DOI: 10.5281 /zenodo.3759722.

\section{ACKNOWLEDGMENTS}

The Swedish Research Council (Swedish Research Links 20126074 and 2016-05857), the Academy of Finland (RP, grant no. 298817), and the Australian Research Council (VMA, grant LP120200557) are gratefully acknowledged for financial support. S.S.N. thanks the Swedish Institute for a postdoctoral research award (00045/2014). J.J.E.M. is grateful to the International Foundation for Sciences' (IFS) financial support. Authors acknowledge Mr. Frank M. Mbago, a senior taxonomist and curator at the Herbarium of the Department of Botany, University of Dar es Salaam, for locating and identifying the plant species in the reported investigation. The Swedish NMR Centre is acknowledged for access to an 800 $\mathrm{MHz}$ spectrometer. The project made use of the NMR Uppsala infrastructure, which is funded by the Department of Chemistry-BMC and the Disciplinary Domain of Medicine and Pharmacy.

\section{REFERENCES}

(1) Lovett, J.; Clarke, G. P., Morinda asteroscepa. The IUCN Red List of Threatened Species 2019: e.T34858A2856538.

(2) Hamilton, A. C.; Bensted-Smith, R. Forest Conservation in the East Usambara Mountains; IUCN: Tanzania, 1989; Vol. 15.

(3) Odutuga, A.; Dairo, J.; Minari, J.; Bamisaye, F. Res. J. Pharm. 2010, 4, 78-82.

(4) Sang, S.; Cheng, X.; Zhu, N.; Stark, R. E.; Badmaev, V.; Ghai, G.; Rosen, R. T.; Ho, C.-T. J. Agric. Food Chem. 2001, 49, 4478-4481.

(5) Deng, S.; West, B. J.; Jensen, C. ISRN Anal. Chem. 2012, 2012, 1.

(6) Phakhodee, W. Walailak J. Sci. Technol. 2012, 9, 173-188.

(7) Ali, A.; Ismail, N.; Mackeen, M.; Yazan, L.; Mohamed, S.; Ho, A.; Lajis, N. Pharm. Biol. 2000, 38, 298-301.

(8) Rath, G.; Ndonzao, M.; Hostettmann, K. Int. J. Pharmacogn. 1995, 33, 107-114.

(9) Takashima, J.; Ikeda, Y.; Komiyama, K.; Hayashi, M.; Kishida, A.; Ohsaki, A. Chem. Pharm. Bull. 2007, 55, 343-345.

(10) Jasril, L. N.; Mooi, L. Y.; Abdullah, M. A.; Sukari, M. A.; Ali, A. M. Asia Pac. J. Mol. Biol. Biotechnol. 2003, 11, 3-7.

(11) Umezawa, K. Japan Kokai Tokyo Koho JP 1992, 6, 736.

(12) Akihisa, T.; Matsumoto, K.; Tokuda, H.; Yasukawa, K.; Seino, K. -i.; Nakamoto, K.; Kuninaga, H.; Suzuki, T.; Kimura, Y. J. Nat. Prod. 2007, 70, 754-757.

(13) Wu, Y.-B.; Zheng, C.-J.; Qin, L.-P.; Sun, L.-N.; Han, T.; Jiao, L.; Zhang, Q.-Y.; Wu, J.-Z. Molecules 2009, 14, 573-583.

(14) Tamura, S.; Kubata, B. K.; Itagaki, S.; Horii, T.; Taba, M. K.; Murakami, N. Bioorg. Med. Chem. Lett. 2010, 20, 1520-1523.

(15) Nivas, D.; Gaikwad, D.; Chavan, P. Etnopharm. 2010, 2, 1-11.

(16) West, B.; Deng, S.; Isami, F.; Uwaya, A.; Jensen, C. Foods 2018, $7,58$.

(17) Wang, M.-Y.; West, B. J.; Jensen, C. J.; Nowicki, D.; Su, C.; Palu, A. K.; Anderson, G. Acta Pharm. Sin. 2002, 23, 1127-1141.

(18) Maeda, G.; Munissi, J. J. E.; Lindblad, S.; Duffy, S.; Pelletier, J.; Avery, V. M.; Nyandoro, S. S.; Erdelyi, M. J. Nat. Prod. 2020, 83, 316-322.

(19) Maeda, G.; Van der Wal, J.; Gupta, A. K.; Munissi, J. J. E.; Orthaber, A.; Sunnerhagen, P.; Nyandoro, S. S.; Erdelyi, M. J. Nat. Prod. 2020, 83, 210-215.

(20) Nyandoro, S. S.; Maeda, G.; Munissi, J. J. E.; Gruhonjic, A.; Fitzpatrick, P. A.; Lindblad, S.; Duffy, S.; Pelletier, J.; Pan, F.; Puttreddy, R.; Avery, V. M.; Erdelyi, M. Molecules 2019, 24, 2746. 
(21) Nyandoro, S. S.; Munissi, J. J.; Kombo, M.; Mgina, C. A.; Pan, F.; Gruhonjic, A.; Fitzpatrick, P.; Lu, Y.; Wang, B.; Rissanen, K.; Erdelyi, M. J. Nat. Prod. 2017, 80, 377-383.

(22) Nyandoro, S. S.; Munissi, J. J.; Gruhonjic, A.; Duffy, S.; Pan, F.; Puttreddy, R.; Holleran, J. P.; Fitzpatrick, P. A.; Pelletier, J.; Avery, V. M.; Rissanen, K.; Erdelyi, M. J. Nat. Prod. 2017, 80, 114-125.

(23) Nyandoro, S. S.; Ndanu, J.; Munissi, J. J.; Gruhonjic, A.; Fitzpatrick, P. A.; Landberg, G.; Lu, Y.; Wang, B.; Pan, F.; Rissanen, K.; Erdelyi, M. J. Nat. Prod. 2015, 78, 2045-2050.

(24) Robien, W. Monatsh. Chem. 2019, 150, 927-932.

(25) Dinda, B.; Debnath, S.; Majumder, S.; Arima, S.; Sato, N.; Harigaya, Y. Indian J. Chem. 2005, 44B, 2362-2366.

(26) Byrne, L.; Sasse, J.; Skelton, B.; Suksamrarn, A.; White, A. Aust. J. Chem. 1987, 40, 785-794.

(27) Kanchanapoom, T.; Kasai, R.; Yamasaki, K. Phytochemistry 2001, 58, 337-341.

(28) Guo, S.-J.; Gao, L.-M.; Cheng, D.-L. Pharm. 2001, 56, 178180.

(29) Tan, J.-J.; Tan, J.-M.; Tan, C.-H.; Qu, S.-J.; Zhu, D.-Y. Nat. Prod. Res. 2012, 26, 1213-1217.

(30) Nyandoro, S. S.; Munissi, J. J.; Gruhonjic, A.; Duffy, S.; Pan, F.; Puttreddy, R.; Holleran, J. P.; Fitzpatrick, P. A.; Pelletier, J.; Avery, V. M. J. Nat. Prod. 2017, 80, 114-125.

(31) Duffy, S.; Avery, V. M. Am. J. Trop. Med. Hyg. 2012, 86, 84-92. 